\title{
「直交梁を有する柱 $\mathrm{RC} ・$ 梁 $\mathrm{S}$ とする梁貫通形式内部柱梁接合部の耐力評価 に関する研究」に対する討論
}

(西村泰志，堀江耕平著 日本建築学会構造系論文集，第76巻，第666号，1523-1531，2011年 8 月号掲載）

DISCUSSION ON “PREDICTIONS ON STRENGTH OF INTERIOR STEEL BEAM-REINFORCED CONCRETE COLUMN JOINTS WITH TRANSVERSE BEAMS” (Yasushi NISHIMURA and Kohei HORIE, J. Struct. Constr. Eng., AIJ, Vol. 76, No. 666, 1523-1531, Aug., 2011)

堀田久人*

\section{Hisato HOTTA}

\begin{abstract}
The above mentioned paper deals with the ultimate strength of beam-column joint panel consist of two-directional $\mathrm{H}$-shaped steel beams and R/C interior column, based on the additional theorem.

The discusser's arguments are as follows;

1) The equations (4), (31) and (35) must be incorrect according to the discusser's understanding.

2) In proposed simplified prediction method, the condition on an amount of longitudinal reinforcement of column and axial force subject to column by which the prediction method is applicable should be specified.
\end{abstract}

Keywords : S beam-RC column joints, stress transferring mechanism, ultimate shear strength RCS 柱梁接合部, 応力伝達機構, せ九断而力

\section{1.はじめに}

日頃の不勉強で、表記貴論文の前段論文等 1)を見過ごしていまし た点、ただただ反省するばかりですが、今回表記貴論文を目にし、 本討論者もまた、柱は $\mathrm{SC}$ 柱と構造形式は異なりますが、直交梁を 有するはり $\mathrm{S}$ 、柱 $\mathrm{SC}$ 柱の柱梁接合部に関して同様の論文 2)を発表 した身として、大変興味深く読ませていただきました。しかしなが ら、幾つかの部分で本討論者の理解を超えた論が展開されておりま すので、疑問を解消したく、ここに討論をお願い寸る次第です。

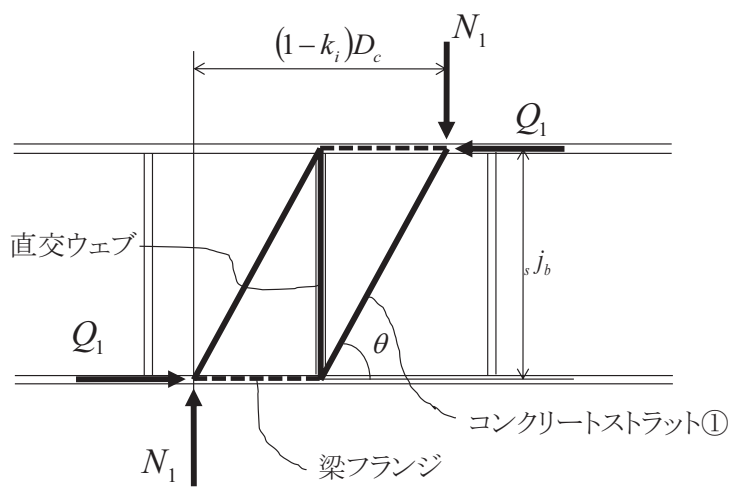

討論図 1 コンクリートストラット(1) によるせん断抵抗機構

\section{2. 内部パネルのせん断耐カについて}

内部パネルのせん断耐力として貴論文式(4)が示されています。こ れは、内部パネルに形成されるコンクリートストラット(1)と(2)の耐 力負担の和として示されていますが、右辺第 1 項、第 2 項のいずれ も理解できません。

討論図 1 に本討論者の理解の範囲でストラット(1)を含むせん断力 抵抗機構を示します。図中、 $\theta$ の角度を為す斜材がコンクリートス トラット(1)を、鉛直部材が直交梁のウェブを示します。この 2 者で は力が閉じていませんので、さらに破線で示した恐らく梁フランジ がその役割を担う水平材があり、図のようなトラスを形成するもの と存じます。図の $N_{1}$ は貴論文における $\min \left({ }_{i} Q_{\text {con } 1, i} Q_{T}\right)$ に相当するもの です。力の釣り合いから、このトラス機構によるせん断耐力 $Q_{1}$ は、

$$
Q_{1}=N_{1} \frac{\left(1-k_{i}\right) D_{c}}{{ }_{s} j_{b}}
$$

となるものと存じます。しかるに貴論文式(5)を式(4)に代入すれば、 式(4)の右辺第 1 項は、式(討 1 )の $1 / 2$ にしかなりません。

ストラット(2)を含む抵抗機構についてはさらに疑問です。貴論文の 論に従えば、抵抗機構は討論図 2 のようになろうかと存じます。斜 材がストラット(2)を、水平材が両側支圧板と梁フランジからなる引 張材（ウェブは純せん断降伏を仮定しているので引張力を負担しな い)です。この 2 者ではやはり力が閉じませんので、破線で示す斜 材が存在するはずですが、コンクリートは既にストラット(1)が交差

\footnotetext{
$*$ 東京工業大学理工学研究科建築学専攻 准教授 $\cdot$ 博士 (工学 $)$
} 
する部分であり、また梁ウェブは純せん断降伏を仮定されているの で、この担い手が見当たりません。また、内部の斜材の圧縮力と釣 り合う $N_{2}$ で示した外力は何なのか理解できなくなります。そこで、 外力の作用位置間距離を式(4)の右辺第 2 項の $D_{c}-t_{f b p}$ に合わせて討 論図 2 を書き直したものが討論図 3 です。この場合、破線で示した 斜材は引張材に転じますが、やはりこの担い手が見当たりません。 また、このときの $N_{2}$ はストラット(2)の圧縮力の鉛直成分と破線で示 した斜材の引張力の鉛直成分の和になっているはずであり、式(9)、 式(10)で示されるものとは異なるものと考えられます。

\section{3. 外部パネルのせん断耐カについて}

少し細かくなりますが、式(31)についてお伺いします。本式は外 部パネルのストラット機構において、直交鉄骨のフランジ板の面内 曲げ耐力によってせん断耐力が規定される場合の式と理解します。 討論図 4 に本討論者の理解の範囲で機構を図示します。 1 枚のフラ ンジ板に作用する水平力は貴論文の図 2 の(c)、式(27)、及び式(29) から $(1 / 2) R_{f b} \cos \alpha$ と理解されます。この作用力によってフランジ交 差部（図の破線部）でフランジ板が曲げ降伏するものとすると、フ ランジ板の面内方向の曲げに対する全塑性モーメントを $M_{p}$ 、モーメ ントアームの長さを $l_{m a}$ とすれば、

$$
\frac{1}{2} R_{f b} \cos \alpha=M_{p} / l_{m a}
$$

となります。 $l_{m a}$ は図から、 $l_{m a}=\left(B_{c}-{ }_{s} b-b_{b}\right) / 4$ となると思いますが、 式(討 2) と式(31)を見比べると、 $l_{m a}=B_{c}-{ }_{s} b-b_{b}$ となっています。これ は表記ミスでしょうか。あるいはどのような機構を考えておられる のでしょうか。

\section{4. 簡便な耐力評価式について}

式(35)について、式(1)に「支圧力が $0.3 D_{c s} b$ の領域に作用する」 として耐力を求めると、

$$
{ }_{i} M_{b}=0.105 \cdot D_{c}^{2} \cdot{ }_{s} b \cdot \lambda \cdot F_{c}
$$

となりますが、これも表記ミスでしょうか。同様の式は文献 1)にも 見られます。

また、簡便な耐力評価式の提案意図として貴論文 4 章の冒頭で「高 圧縮軸力あるいは引張軸力を受ける部分を除いて、支圧およびせん 断耐力とも軸力に関わらず一定の耐力を示しており」(傍点討論者付 記）とありますが、本当でしょうか。例えば、内部パネルの耐力が 式(35)で決まり、外部パネルの耐力が式(38)で決まる場合で、直交 鉄骨の幅が柱幅の $1 / 3$ である場合、接合部パネルに作用する鉛直力 は、 $0.3 D_{c s} b \lambda F_{c}+(1 / 3) D_{c}\left(B_{c}-{ }_{s} b\right)$ と相当大きなものになります。こ れに釣合う接合部への外力は柱軸力及び柱主筋の引張力ですから、 柱軸力が零で、条件を満たすためには主筋量が、 $p_{g} \sigma_{y} \geq 0.3 D_{c s} b \lambda F_{c}$ $+(1 / 3) D_{c}\left(B_{c}-{ }_{s} b\right)$ を満たす必要があります。これは柱の主筋量とし てはかなり多い部類に入るものと思われます。提案式の適用範囲に として、柱軸力と柱主筋量に関して何らかの条件が提示されるべき であると思われますがいかがでしょうか。

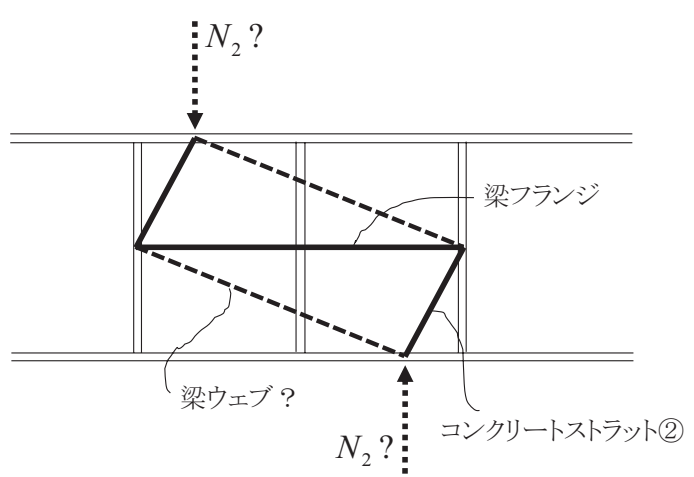

討論図 2 コンクリートストラット(2) によるせん断抵抗機構

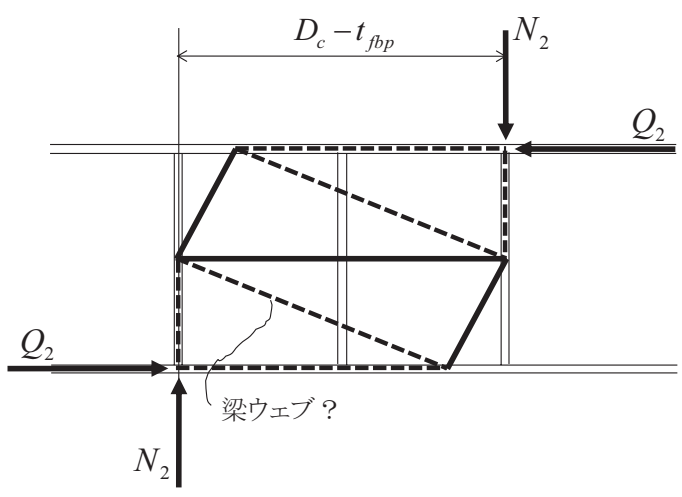

討論図 3 コンクリートストラット(2) によるせん断抵抗機構(改)

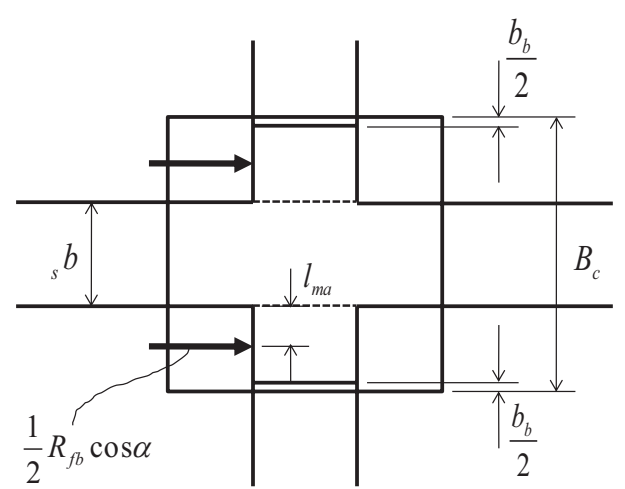

討論図 4 直交フランジの曲げ降伏で決まる外部 パネルのアーチ機構によるせん断耐力

5. まとめ

以上、 3 項目にまとめました疑問点について、ご説明いただけれ ば幸甚です。ご回答の程よろしくお願い申し上げます。

\section{参考文献}

1) 西村泰志、堀江耕平 : 柱 $\mathrm{RC} \cdot$ 梁 $\mathrm{S}$ とする梁貫通形式内部柱梁接合部の耐 力評価に関寸る研究、日本建築学会構造系論文集 第 75 巻 第 654 号、 pp.1557-1565, 2010. 8

2) 鈴木敏郎、滝口克己、堀田久人 : $45^{\circ}$ 方向加力を受ける鉄骨フープ筋コン クリート柱鉄骨はり接合部の終局強度、日本建築学会構造系論文集 第 463 号、pp.135-142, 1994. 9 